\title{
My Sister's Voice: Guiding My Hope as a Teacher and Teacher Educator for Teaching and Learning
}

\author{
Remonia Stoddart-Morrison
}

\begin{abstract}
Schools are relational places where the meeting of characters, stories, experiences, and understandings move about each other daily. In the busyness of school life, time is usually not taken to listen to, observe, and share the stories and experiences of others; to shift from a condition of moving about to a place where we are walking alongside. The narratives provided here are reflections on my experiences of my time in school as student, teacher, and administrator. I write these to honor my sister's voice and the many voices that fueled my hope as a teacher and teacher educator for teaching and learning.
\end{abstract}

\section{Background}

In his book, "The Courage to Teach," Parker J. Palmer (2007) posited that teaching is a profession that attracts people for reasons of the heart and because of this, teachers sometimes lose heart. They continuously ask themselves how they can regain the hope, passion, and zeal they once had so they can contribute effectively to teaching and learning within their classrooms. I propose that this can be achieved through recalling and confronting one's experiences and stories of the past, present, and the yet to come (Yoder \& Strong-Wilson, 2016), and by identifying that which guided their aspiration and desire to follow this path and contribute to this profession. In so doing, teacher educators and teachers will open the space up for the stories of others (students, colleagues, family, friends, strangers) to be layered and nested within their own stories, which will allow for the "and yet" (Aoki, 1996/2005). "And yet" signifies possibilities, multiplicity, divergence, and the not-yet considered, thus forcing us away from a one-eyed view of teaching and learning into a multi-lens view.

\section{Voice in the Present}

Teacher educators and teachers are encouraged to be strong poets. Barone (2000) defines strong poets as compelling storytellers who can continuously revise their stories based on their own experiences and those of their students. Strong poets are those who can work through mental defences and see students as having a story of their own to be told or to tell themselves (Cavarero, 2000). Strong poets are also those who can embark first on an inner journey, since teaching is a human activity that projects the conditions of the teacher's soul onto their students, what is being taught, and the different ways of being together (Palmer, 2007).

Born into a country where only 10 percent of the population pursues postsecondary education, and in a community where the girls complete high school but without acquiring high school certification or they 
drop out of school due to pregnancy, my sister's voice was my guide, my facilitator, my coach. My sister was the first of eight children - I was the seventh. She was 16 years my senior and wasn't shy about talking. No matter what the topic was, her voice could always be heard, even when she was miles away.

As a child, while she combed my hair, she would constantly remind me of how beautiful I was and how I could accomplish great things. I loved hearing her say that, and even though I did not necessarily believe it at the time — since I was filled with sores all over and my mother seemed to always forget that I existedhearing my sister utter those words gave me hope. My care, and that of three of my other sisters, fell to her. Even with all she had to do, she took very good care of us with the little means she had. She ensured that we were fed, had clothes on our backs and, most importantly, attended school. She firmly believed that attending school was of utmost importance because if you were not there, then you could not learn what was being taught.

What are those things that shape, encourage, or give hope in teaching and learning? Farrar (as cited in Sandel, 2002) encourages beginning teachers to listen to and project the voice of hope. She noted that they should have the hope of protest. It is this hope that allows a teacher to go against all that says students are failures. A hope that is rooted in the emancipation of students. A hope of power which comes from students finding their voices-voices of distinction, diversity, creativity, and liberation. Hope brings possibilities and possibilities bring change; therefore no one should be without hope. Teacher educators and teachers must endeavor to make their classrooms spaces of hope.

My sister's methods of discipline were always strict but loving; she talked more than she punished and at that time it did not seem to work, as I often returned to doing the exact thing she warned against. I have found, however, that as I grew older, the lessons have stuck with me and have helped me to navigate many of the obstacles that I encountered on my journey. I recall wanting to go to a party and being told by her I wasn't allowed to go, so I snuck out of the house during the night to attend the party. I had a great time and thought that I would sneak back in without her noticing. She had awoken long before, checked, and found that I was gone, and was awaiting my return. I did get a beating, but then she spoke gently to me of all the things that could have happened to me, the dangers I could have encountered, of how she panicked when she realized that I was not in the house and of how happy she was that I returned safely. Now that I have kids of my own and my students at school, I understand how important it is to guide our children in the right path and how terrifying it can be when it seems they could come to some harm.

As teacher educators and teachers, how often do we allow students the time so that lessons can be learnt? It is so easy for us to feel like giving up, to want to let go and declare that we can't save them all. However, we do not need to let go; students will eventually let go as they leave school sooner or later. When caught in a situation where teachers want to give up on a student, they should consider one of their "screen memories" from earlier life, those closed-off, life companions that dwell both inside and outside the classroom; this will open up narrative spaces (Freud as cited in Britzman, 2004) where strength is achieved and aid offered. 
My sister's words of encouragement were as consistent as she was. She fully expected my sisters and I to work hard, which she insisted would help us get to a better station in life. She worked hard and always reminded us that working hard was also important since all good things take time and effort. I always admired how she never gave up, how she did short programs part-time in order to be better qualified for the job she was doing. I was constantly reminded that if I stuck to it and got up each time I fell, I would definitely make it. Through her life and voice, she shared with me the power of persistence and perseverance.

Is this the same support that teachers are expected to offer to students, and, if so, how do they get to the point of being able to offer that kind of support? Noddings (1984) noted that teachers were to regard students as being "infinitely" more important than the subject matter being taught. When students are considered as such, teachers will put the effort into helping them achieve their potential. To do this, teacher educators should engage in conversations with teachers about them not seeing students as "subjects" and what they do with them as "treatments," but to see them as human beings to be cared for and nurtured (Noddings, 2005).

When my sister spoke of other children, it was always with affection, sympathy, or both. She always found the best in them, even when others thought them to be out of control or "bad." With the little she had-and having to take care of my sisters and I-she always found some way to help another child. She took two children from the rural community in which she grew up, to live with us so as to give them a better chance of succeeding and being able to help their families in return. I remember her saying that children can do remarkable things, but they needed someone to be behind them, to hold them up and light the way when things seemed dark. In other words, each child needed a champion (Pierson, 2013).

Not having the time to attend meetings with teachers or get involved in school events and activities was always worrying for her. She thought that teachers were more responsive to students with whose parent/guardian they had positive interactions. She was always quite critical of this because she noted that most teachers did not take the time to know or understand students' particular situations. She felt if they did, the interactions between them would have been better. When we lived with our aunt and she kept us from school for over three weeks, no one came to find out why we were absent, and, on our return, no one asked what happened. My sister believed in being our brother's and sister's keepers and reminded us to be concerned about the well-being of others at all times.

Responsibilities for student care extend well beyond the classroom. Noddings (2001) speaks to the caring responsibility of teachers requiring profound attention. This encompasses careful attention to students' gestures, body language, and their state of being, which includes both their physical and mental health. Jardine, Friesen, and Clifford (2006) also add that teachers need to draw closer to the students and direct them as they share their individual and combined experiences in the "lifeworld."

My sister got married and had children, and after a while her husband did not like the fact that she was responsible for my other siblings and I. Though it pained her, she sent us to other relatives, since my mother was living in another country and did not offer any help for our care. My sister contributed 
financially to our care and made sure we were still attending school regularly. However, she could not see us often as she had to work. My aunt, with whom we were living at that time, treated us horribly. I didn't tell my sister about it because she had done so much and was going through so much. I didn't want her to blame herself for leaving us with our aunt. She eventually found out and took us from our aunt, which caused additional problems with her husband. She decided that she would not allow anything to hinder her from being there for us and helping us to achieve our full potential.

\section{Dual Voice (Between the Present and the Distant)}

My sister worked at the University of Technology, Jamaica (formerly, the College of Arts, Science and Technology [CAST]) and when it was summer and other holidays, she would take me to work with her. There were times that I resented it because we had to leave home early to get to the university. She was the supervisor in the cafeteria and had to oversee the preparation of breakfast for students and staff. She did this because she wanted me to get a feel for the university and a sense that I too could be a student there. She would urge me to walk to the various departments and see the summer program students in classes, to see those on the track and in the pool, to look at brochures and get familiar with the course requirements. This made me believe that I had a place in the university, that I had a right to be there when the time came.

While I was in high school, I got into an argument with a classmate (who was from an affluent family). It was the vice principal's professional opinion that I was out of line for even thinking of arguing with this student. She looked directly at me, told me that I was nothing and asked how I could have the cheek to address this other student in that manner. She told me I came from nowhere and would be nothing, as opposed to the other student who was already somebody and would become somebody later in the future. I felt demoralized, but I went home and waited to hear the voice that would reassure me, the warm encouraging voice that would dispel the negativity that I heard earlier. My sister reminded me that I was created for a special purpose, and the sad thing was that some individuals are blind, therefore they cannot see it. How very melancholy it is that persons who are set in a position to guide students and should have sight are the very ones who are visionless to the potential in students. I returned to school the next day, empowered from the words spoken by my sister, ready to take on the challenges of school with renewed vigor.

Justice for youth and advocacy by teachers for students is an important aspect of education, more specifically, teaching and learning. Teachers advocating on behalf of their students help students make the pain they feel bearable; it clears up confusion and makes them stronger (Quindlen as cited in Gruwell, 2007). Social justice and advocacy is about treating people ethically, and if teachers are to impart that to students they must be able to not only speak of the concepts, but also model them. Being ethical towards others means being mindful of the words we utter. Teachers educators and teachers make intentional word choices (Rosado-McGrath, 2016) so that their words will echo in students and create goodness as they speak. 
While in university, I did not talk with my sister as often, but the advice and direction her voice gave were still in my memories and would continually guide me. When I failed a course, I did not feel daunted as others did because I could hear my sister say: "It's not the end of the world. You are alive. Your journey to greatness isn't over. Try again." I was confident that I would complete university because she had set the stage by pushing me forward, just like a mother goat with her kid, pushing him up the hill to get him to the top.

Being proud when I finished university and always grateful for the support I received, my need to give back was always at the forefront of my mind. In the summer after completing my studies, I conducted a class in my community for children. I saw them playing daily in the street and offered to teach them to use the computer in the evenings. Parents agreed, and my sister allowed me to use a space in our home and thus the classes began. Not long after we started I was approached by a teacher in the community wanting to join the class as her school had just acquired some computers and there was no one there who was able to operate them. The training and experience she received in the summer allowed her to not only teach her students to use the computers, but also her fellow teachers. And the gift goes on.

Sharing our experience and passing on what we know is a powerful tool in helping to refuel the passion of teacher educators and teachers (Rosado-McGrath, 2016). Interacting, collaborating, and sharing with colleagues and students is seen as an integral part of professional development (Darling-Hammond \& McLaughlin, 1995).

\section{A Far-Off Voice}

Moving away from home after finishing my degree and after a year of working, I began my life as an adult. I was no longer in the presence of my sister, but her voice was still in my head, and, of course, it comes through the phone when she calls. As I worked as a teacher, I would remember my sister always talking about her disagreement of some policy that my school and others had. She would complain of the senselessness of keeping students outside of school when they are late or the suspension of students for various misdemeanors. She also knew when to be quiet, but even in her quietness her voice has always influenced my conscience, prompting me to act in the students' best interests.

Other quiet voices teach us as teacher educators and teachers (Gruwell, 2007). Parents, students, colleagues, friends, and the media can all be considered teachers and teacher educators (The European Commission, 2013). I sat in the boardroom of my school as part of a disciplinary committee, meeting to discuss and accept (as we had already decided) the recommendation for a student's expulsion. The case was read aloud, and the evidence and actions taken were outlined to the parent in the presence of the child. After all was said, the mother quietly thanked us for all we had done. However, she declared that while we were at the point of giving up, she, on the other hand, would not. She noted that she would try to her last breath to save her child. All the voices-the stories of support my siblings and I had from childhood, from my sister, teachers, and adults in the community-came flooding back to me. I couldn't vote for expulsion and asked that the child be given another chance; I was determined to seek the help of other people who could help him. Three years later at graduation, 
the mother hugged me, and we cried. She thanked me for helping her son, but I was one who was grateful to her for being such a good teacher educator. She had taught me well.

When it seemed that I had to follow the policies outlined by the School Board, I recalled how my sister breathed life into me against all odds and how she gave me chance after chance whenever I erred. She believed in me and would never give up on me, even when it meant giving up something that she wanted. To deal with difficult, uncaring, and uncooperative parents, I recalled my sister saying that I didn't have a choice in who my parents were, which helped me to focus on helping students and doing my best to get through to the parents, working with them for the benefit of the students.

Teachers struggle with students who come from different backgrounds, especially when those backgrounds are different from their own (Rosado-McGrath, 2016). With these different backgrounds come certain unwanted behaviors and difficulties. To deal with these, teachers resort to enforcing institutional rules. A student's parent ran onto the school compound with stones in her hands as students were leaving. She was shouting the name of a teacher and stated that she was going to punish him with the stones since he had punished her son. Her son had used his cellphone (which was not allowed in school) to call his mother. The teacher she was looking for had already left and although it took a long time, we were able to calm her down. The teachers were furious as the incident had put them and other students in danger. They believed the student should be suspended or expelled as he had used a cellphone, which was against school policy, in addition to the fact that someone could have gotten hurt.

This placed me in an awkward position, a borderline place amidst ease and dis-ease (Lugones, 1987). I knew what the parent did was wrong and dangerous, but I did not agree with the action they were suggesting for the student. Teachers expressed their displeasure of my not expelling the student, stating that this showed that I was uncaring for their safety, was being too lenient on the student, and that this would open the opportunity for other students and parents to do the same. I realized that this reaction from the teachers stemmed from the fear of having a live encounter with "otherness" (Yoder \& Strong-Wilson, 2016) in students and because of this fear teachers move to recommending a certain pedagogical treatment for students' conditions and behaviors (Palmer, 2007). Palmer advocates that rather than "rely on stereotypical interpretations of student behaviour, we need to understand their marginality and decode the fear that often drives their lives and ours" (p. 38). Instead of seeking "self-protection" we should choose "generativity," which is described as "creativity in the service of the young" (Palmer, 2007 p. 40). Aoki (1996/2005) also supports this view as he noted that teacher stories, nested with those of their students, allow the teacher to move away from a place of self, a place of anger

and fear, and move to a place where the focus is on the subject (student) where we would be able to linger a little longer to contemplate our actions moving forward.

\section{Implications for Teaching and Learning}

Stories teach us, not only the hearers, but also the tellers: those original to the story and those who will tell and hear them as they are retold. They teach lessons of hope, empathy, values, and morals. Storytelling has a mysterious quality which allows it, from a single story, to move across and inhabit the 
minds of a great many people (Okri,1997). Sharing the stories of my experiences within schools and the experiences of those directly and indirectly connected to my life in and out of school has taught me to reflect on and contemplate how teachers teach and how students learn. As teachers, recalling and sharing experiences through stories with students encourages students to tell and retell their own stories. Retelling involves seeing things in a new light (Clandinin \& Connelly, 2000). It encompasses a change in understanding, a change in thinking, a change in behavior, and a change in attitude.

As teachers, the traditional narrative is that we are the experts within the classroom (Britzman, 1986). With that narrative comes the notion that we have all the knowledge and our task in teaching is to disseminate that knowledge to our students (Britzman, 1986). This narrative requires teachers to talk more than they listen. Storytelling and sharing has an exceptional ability to change that traditional narrative. As we can learn from the experiences of others, both teachers and students have knowledge to share and gain, thus teachers are not burdened by the pressures of having to be the sole experts in their classrooms. Storytelling and sharing makes us better listeners (Cole, 1989, as cited in Clandinin \& Connelly, 2000). As we listen to experiences being shared in stories, we are forced to listen and re-listen to what is being told. Winslade and Monk (2013) call it "double-listening," which is when we can recognize other stories that are parallel to the ones being told. The focus of double-listening is not getting to the "truth," but to build understanding, respect, and collaboration-traits that fully support teaching and learning.

A change in overall attitude can positively affect teaching and learning outcomes. Through stories, teachers can gain an awareness of who students are inside and outside the classroom. Stories provide teachers the opportunity to recognize and appreciate students' unique and collective struggles and how they influence students' learning. Teachers can then direct their classrooms activities and lessons in such a way that will guide students to be tolerant, resulting in more collegial interactions in classrooms and lowering the need for teachers to spend time dealing with conflicts.

Our lives and those of our students may differ. However, these are pathways that must be brought to light through narratives so as to recover a sense of "the possible" (Yoder \& Strong-Wilson, 2016) in classrooms where teachers and students teach and learn. My sister's voice has become my voice, as daily I encourage teachers to see the possible in each student and in each situation. Moreover, I encourage them to try and be the champions for those who have lost their voice through the sharing and nesting of their stories and those of their students. All this with a view to nurturing hope and excellence into the precious souls that are entrusted to our care-and opening potential for continuous teaching and learning.

\section{References}

Aoki, T. (1996/2005). Narrative and narration in curriculum spaces. In W. Pinar \& R. Irwin (Eds.), Curriculum in a new key: The collected works of Ted Aoki. Mahwah, NJ: Lawrence Erlbaum Associates.

Barone, T. (2000). Aesthetics, politics and educational inquiry. Essays and examples. New York, NY: Peter Lang. 
Britzman, D.P. (1986). Cultural myths in the making of a teacher: Biography and social structure in teacher education. Harvard Educational Review, 56(4), 442-457.

Britzman, D.P. (2004). Monsters in literature. Changing English, 11(2), 253-265.

Cavarero, A. (2000). Relating narratives. Storytelling and selfhood. London: Routledge.

Clandinin, D. J., \& Connelly, F. M. (2000). Narrative inquiry: Experience and story in qualitative research. San Francisco, CA: Jossey-Bass.

Darling-Hammond, L., \& McLaughlin, M.W. (1995). Policies that support professional development in an era of reform. Phi Delta Kappan, 76(8), 597-604.

European Commission. (2013). Supporting teacher educators: Teaching the teacher. Brussels: European Commission.

Gruwell, E. (2007). Teach with your heart. Lessons learned from freedom writers. New York, NY: Broadway Books.

Jardine, D.W., Friesen, S., \& Clifford, P.A. (2006). Curriculum in abundance. New Jersey: Lawrence Erlbaun Associates, Publishers.

Lugones, M. (1987). Playfulness, "world"-travelling, and loving perception, Hypatia, 2(2), 3-19.

Noddings, N. (1984). Caring, a feminine approach to ethics and moral education. Berkley, CA: University of California Press.

Noddings, N. (2001). The ethic of caring: Teaching themes of care. Character, 14(2), 675-679.

Noddings, N. (2005). Care in schools. An alternative approach to education (2nd ed.). New York, NY: Teachers College Press.

Okri, B. (1997). A way of being free. London: Phoenix House.

Palmer, P.J. (2007). The courage to teach. Guide for reflection and renewal. San Francisco, CA: Jossey-Bass.

Pierson, R. (2013). Every kid needs a champion.

Retrieved from https://www.ted.com/talks/rita_pierson_every_kid_needs_a_champion

Rosado-McGrath, E. (2016). From burned out to fired up. Teachers reignite their passion to inspire. California: Get Branded Press.

Sandel, L. (2002). Qualities of a language arts teacher. Traits and perspectives, daily inspiration from outstanding educators. Indiana University: ERIC. Retrieved from http://files.eric.ed.gov.login.ezproxy.library.ualberta.ca/fulltext/ED467657.pdf

Winslade, J., \& Monk, G. (2013). When stories clash: Addressing conflict with narrative mediation. Ohio: Taos Institute Publications

Yoder, A., \& Strong-Wilson, T. (2016). "And yet": Storying complexity in teacher narratives. In N. Ng-a-Fook, A. Ibrahim, \& G. Reis (Eds.), Provoking curriculum studies: Strong poetry and arts of the possible in education (pp. 134-149). New York, NY: Routledge. 
My Sister's Voice: Guiding My Hope as a Teacher and Teacher Educator for Teaching and Learning

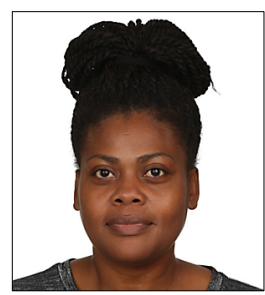

Remonia Stoddart-Morrison is a second-year PhD student in the Department of Secondary Education. The focus of her graduate work is teacher education and more specifically on in-service teacher education and sustaining hope for teaching by looking at teachers' experiences with and understanding of teacher education spaces in high schools. Prior to her studies at the University of Alberta, Remonia worked as a Principal, Vice Principal, Head of Department, and Teacher for over 15 years in a secondary school in Jamaica. 
364 | LEARNing Landscapes | Spring 2018, Vol. 11 No. 2 